\title{
Penentuan Jumlah Kelas Matakuliah Menggunakan Fuzzy Tsukamoto Dan Metode K-Means Cluster
}

\author{
Yessy Fitriani ${ }^{1}$; M. Farid Rifai ${ }^{2}$; M. Yoga Distra . $^{3}$ \\ ${ }^{1,2,3}$ Program Studi Teknik Informatika, Sekolah Tinggi Teknik PLN \\ 1yessy.fitriani@sttpln.ac.id
}

\begin{abstract}
The prediction of the number of courses is done by the department before making a schedule for each course. In practice the number of classes in each course has a different number and there is often an opening or closing class when compiling a KRS due to the number of classes that are not in accordance with the number of students. A system is needed to produce a number of classes, so that it can reduce the number of opening classes because the demand for a higher number of classes is in the class because of the interest in a class that will be opened. Fuzzy methods are used to predict students who will repeat the course based on student force and value variables. The K-Means method is used to classify the subjects with the number of students converted into 2 groups based on the number of students who have been taken and the number of students who repeat a number of subjects. The two methods used are implemented in the application system to predict the number of classes. The results of the fuzzy and $K$-method processes mean the output of the application predictions the number of classes.
\end{abstract}

Keywords: predictions, subjects, fuzzy, $k$-means

\begin{abstract}
ABSTRAK
Prediksi jumlah matakuliah dilakukan pihak jurusan sebelum membuat jadwal setiap matakuliah. Pada prakteknya jumlah kelas setiap matakuliah memiliki jumlah yang berbeda dan sering terjadi pembukaan atau penutupan kelas saat penyusunan KRS akibat dari jumlah kelas yang tidak sesuai dengan jumlah mahasiswa. Diperlukan sistem untuk menghasilkan prediksi jumlah kelas, sehingga dapat mengurangi kemungkinan pembukaan kelas baru karena peminatnya melebihi kapasitas kelas yang ada ataupun penutupan kelas karena kurangnya peminat pada suatu kelas yang akan dibuka. Metode fuzzy digunakan untuk memprediksi kecenderungan mahasiswa yang akan mengulang suatu matakuliah berdasarkan variabel angkatan dan nilai mahasiswa. Metode K-Means digunakan untuk mengelompokkan matakuliah dengan jumlah mahasiswa yang mengulang menjadi 2 kelompok berdasarkan jumlah mahasiwa yang sudah pernah mengambil dan jumlah mahasiwa yang mengulang suatu matakuliah. Dari kedua metode yang digunakan diimplementasikan ke dalam sistem aplikasi prediksi jumlah kelas. Hasil dari proses metode fuzzy dan $K$ - means menjadi output pada aplikasi prediksi jumlah kelas.
\end{abstract}

Kata kunci: prediksi, matakuliah, fuzzy, k-means, kelas 


\section{PENDAHULUAN}

Prediksi jumlah matakuliah dilakukan pihak jurusan sebelum membuat jadwal setiap matakuliah. Pada prakteknya jumlah kelas setiap matakuliah memiliki jumlah yang berbeda dan sering terjadi pembukaan atau penutupan kelas saat penyusunan KRS akibat dari jumlah kelas yang tidak sesuai dengan jumlah mahasiswa. Diperlukan sistem untuk menghasilkan prediksi jumlah kelas, sehingga dapat mengurangi kemungkinan pembukaan kelas baru karena peminatnya melebihi kapasitas kelas yang ada ataupun penutupan kelas karena kurangnya peminat pada suatu kelas yang akan dibuka.

Pada prakteknya jumlah kelas yang dibuka saat proses penyusunan Kartu Rencana Studi (KRS) tidak sesuai dengan jumlah mahasiswa yang akan mengambil mata kuliah tersebut. Kesalahan dalam memprediksi jumlah kelas pada mata kuliah tertentu disebabkan karena pihak sekretariat jurusan Teknik Informatika hanya mengacu pada jumlah kelas semester sebelumnya dan data statistik nilai tidak lulus suatu matakuliah tahun ajaran sebelumnya. Sebagai contoh untuk memprediksi jumlah kelas matakuliah jaringan komputer pada semester 5, maka jurusan akan mengacu pada banyaknya kelas semester sebelumnya, yaitu semester 4 dan dengan mempertimbangkan persentase data statistik nilai mahasiswa yang tidak lulus nilai jaringan komputer tahun ajaran sebelumnya.

Namun prediksi tersebut sering diluar dugaan,dikarenakan peminat pada setiap matakuliah berbeda-beda, terkadang terdapat mahasiswa yang seharusnya mengambil matakuliah wajib pada semester tertentu tetapi sudah mengambil pada semester sebelumnya, atau terdapat mahasiswa yang tidak lulus(mendapat nilai D atau E) kemudian berniat ingin mengulang matakuliah tersebut atau mahasiswa yang lulus tetapi nilai yang didapat kurang memuaskan sehingga memutuskan untuk mengulang matakuliah tersebut. Beberapa kemungkinan tersebut bisa dijadikan pertimbangan untuk menentukan banyak peminat untuk setiap matakuliah sehingga dapat memprediksi jumlah kelas lebih efisien dan meminimalisasi masalah pada saat pembagian kelas suatu matakuliah yang akan terjadi pada saat penyusunan KRS berlangsung.

Dari beberapa kondisi tersebut, saat proses penyusunan KRS berlangsung timbul beberapa masalah seperti, mahasiswa tidak mendapat kuota kelas matakuliah wajib karena kelas sudah penuh atau penutupan kelas akibat mahasiswa dalam 1 kelas kurang dari kuota minimal yaitu 13 mahasiswa. Akibat dari itu mahasiswa yang tidak mendapat kelas melaporkan ke pihak jurusan untuk meminta pembukaan kelas baru. Di sisi lain untuk membuka kelas baru pihak jurusan perlu mempertimbangkan ketersediaan ruang kelas dan dosen yang mengajar. Keterbatasan dosen terkadang juga menyebabkan kelas baru tidak dapat dibuka. Berdasarkan undang undang nomor 12 tahun 2012 tentang pendidikan perguruan tinggi, utamanya pasal 56 tentang pangkalan data pendidikan tinggi(selanjutnya disebut PD Dikti) pada butir ke 5 yaitu masyarakat dapat memeriksa kesehatan perguruan tinggi dan program studi melalui menu "Profil PT" dengan mencermati rasio dosen terhadap mahasiswa. Rasio ideal program ideal studi adalah 1:20 untuk eksakta dan 1:30 untuk ilmu sosial dengan toleransi 50\%.

Pada hasil penelitian yang telah dilakukan oleh Siti Hamidah tahun 2016 dengan judul Analisis Komparasi Meode Tsukamoto dan Sugeno dalam Prediksi Jumlah Siswa Baru untuk prediksi perolehan jumlah siswa baru, metode tsukamoto menghasilkan tingkat akurasi sebesar 90,41\% dengan nilai AFER ratarata simpangan yang terjadi antara data riil dengan data hasil prediksi sebesar 9,59\%. Dan metode sugeno mempunyai tingkat akurasi sebesar 85,92\% dengan nilai AFER dengan ratarata simpangan yang terjadi antara data riil dengan data hasil prediksi sebesar 14,08\%, sehingga analisis yang dihasilkan menunjukkan bahwa metode tsukamoto mempunyai tingkat akurasi yang lebih tingi dibandingkan dengan metode sugeno untuk memprediksi perolehan jumlah siswa baru gelombang satu pada SMK Shandy Putra Banjarbaru. [1]. 
Berdasarkan uraian diatas penulis mencoba membuat suatu sistem untuk menghasilkan output jumlah kelas suatu matakuliah yang akan dibuka pada jurusan Teknik Informatika STTPLN Jakarta, dalam hal ini penulis melakukan penelitian dengan judul: "Prediksi Jumlah Kelas Suatu Matakuliah Menggunakan Metode Fuzzy (Studi Kasus : Teknik Informatika STT-PLN Jakarta)". Pada penelitian ini penullis menggunakan metode fuzzy yaitu fuzzy tsukamoto yang digunakan untuk memprediksi kecenderungan mahasiswa yang akan mengulang suatu matakuliah berdasarkan variabel angkatan dan nilai mahasiswa. Dari hasil jumlah mahasiswa yang sudah mengambil dan mahasiswa yang mengulang maka dilakukan klusterisasi untuk mengelompokan matakulliah menggunakan metode K-Means.Metode Kmeans digunakan untuk mengelompokkan matakuliah dengan jumlah mahasiswa yang mengulang menjadi 2 kelompok berdasarkan jumlah mahasiwa yang sudah pernah mengambil dan jumlah mahasiwa yang mengulang suatu matakuliah. Dari kedua metode yang digunakan diimplementasikan ke dalam sistem aplikasi prediksi jumlah kelas. Hasil dari proses metode fuzzy dan Kmeans menjadi output pada aplikasi prediksi jumlah kelas.

\section{LANDASAN TEORI}

\section{a. Prediksi}

Prediksi adalah suatu proses memperkirakan secara sistematis tentang sesuatu yang paling mungkin terjadi di masa depan berdasarkan informasi masa lalu dan sekarang yang dimiliki, agar kesalahannya (selisih antara sesuatu yang terjadi dengan hasil perkiraan) dapat diperkecil. Prediksi tidak harus memberikan jawaban secara pasti kejadian yang akan terjadi, melainkan berusaha untuk mencari jawaban sedekat mungkin yang akan terjadi [2].

\section{b. Text Mining}

Konsep logika fuzzy pertama kali diperkenalkan oleh Professor Lotti A. Zadeh dari Universitas California tahun 1965. Logika fuzzy merupakan generalisasi dari logika klasik (crisp set) yang hanya memiliki dua nilai keanggotaan yaitu 0 dan 1 . Dalam logika fuzzy nilai kebenaran suatu pernyataan berkisar dari sepenuhnya benar sampai dengan sepenuhnya salah[3]. Fuzzy logic berhubungan dengan ketidakpastian yang telah menjadi sifat alamiah manusia, mensimulasikan proses pertimbangan normal manusia dengan jalan memungkinkan komputer untuk berperilaku sedikit lebih seksama dan logis daripada yang dibutuhkan metode komputer konvensional. Pemikiran dibalik pendekatan ini adalah pengambilan keputusan tidak sekadar persoalan hitam dan putih atau benar dan salah, namun kerapkali melibatkan area abuabu, dan hal itu dimungkinkan[3]

\section{METODOLOGI PENELITIAN}

\section{a. Langkah-langkah Penelitian}

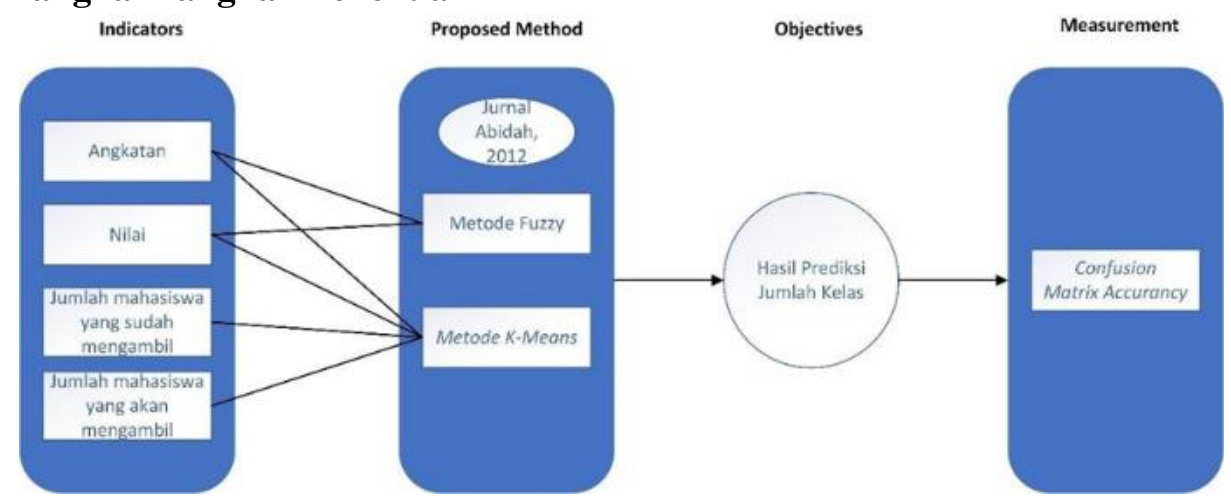

Gambar 1. Bagan Metodologi 
a) Indicators

Pada tahap ini atribut yang digunakan untuk diproses dan diolah merupakan data rekapitulasi nilai mahasiswa untuk setiap matakuliah. atribut yang digunakan yaitu nilai mahasiswa dan angkatan.

b) Proposed Method

Proposed Method merupakan metode tahapan penyelesaian yang diusulkan. Pada penelitian ini digunakan metode Fuzzy yang digunakan untuk menentukan mahasiswa pada suatu matakuliah mengulang atau tidak dan K-Means untuk pengelompokkan matakuliah berdasarkan mahasiswa yang sudah mengambil dan mahasiswa yang akan mengulang.

c) Objectives

Objectives merupakan hasil yang ingin diperoleh dengan menggunakan metode yang diusulkan. Target yang ingin diperoleh dari penelitian ini adalah menghasilkan prediksi jumlah kelas setiap matakuliah berdasarkan atribut yang telah ditentukan.

d) Measurement

Measurement merupakan proses pengukuran tingkat akurasi dari validitas pengujian hasil metode. Dalam hal ini Teknik pengujian yang dilakukan menggunakan metode Confusion Matrix Accurancy[4].

\section{HASIL DAN PEMBAHASAN}

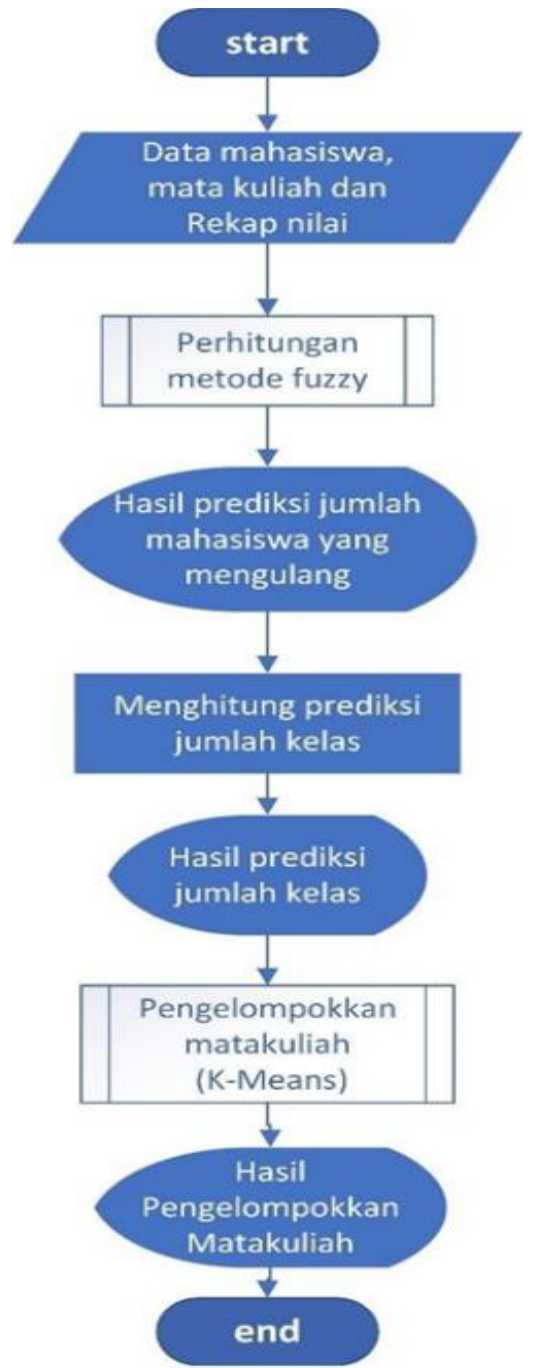

Gambar 2. Alur Kerja Sistem 
Pada flowchart diatas menjelaskan beberapa tahap dalam proses prediksi jumlah kelas:

1. Input data

Berikut merupakan data awal sebelum masuk ke pemrosesan data. Kemudian dari data awal, dipilih atribut yang akan digunakan untuk proses perhitungan fuzzy. Terdapat 2 atribut yang akan digunakan yaitu NIM dan Nilai mahasiswa. Atribut NIM diambil 4 karakter dari kiri untuk mengetahui angkatan dari setiap mahasiswa. Contoh NIM 201531225 menjadi 2015, kemudian atribut nilai yang karakter dilakukan pembobotan untuk diubah menjadi angka.

Tabel 1. Pembobotan Atribut Nilai Mahasiswa

\begin{tabular}{|c|c|}
\hline Nilai & Bobot \\
\hline A & 4 \\
\hline A- & 3,75 \\
\hline B+ & 3,5 \\
\hline B & 3 \\
\hline B- & 2,75 \\
\hline C+ & 2,5 \\
\hline C & 2 \\
\hline D & 1 \\
\hline E & 0 \\
\hline
\end{tabular}

\subsection{Perhitungan Metode Fuzzy}

Pada tahap ini dilakukan proses perhitungan metode fuzzy untuk menentukan mahasiswa yang akan mengulang suatu mata kuliah. Di dalam metode ini, terdapat tiga langkah yang akan digunakan untuk menentukan nilai mahasiwa dari data kualitatif menjadi kuantitatif (dalam bentuk angka), adaupun alur yang akan dilaksanakan seperti ini: mendefinisikan variabel, inferensi, dan defuzzifikasi (menentukan output crisp) [5].

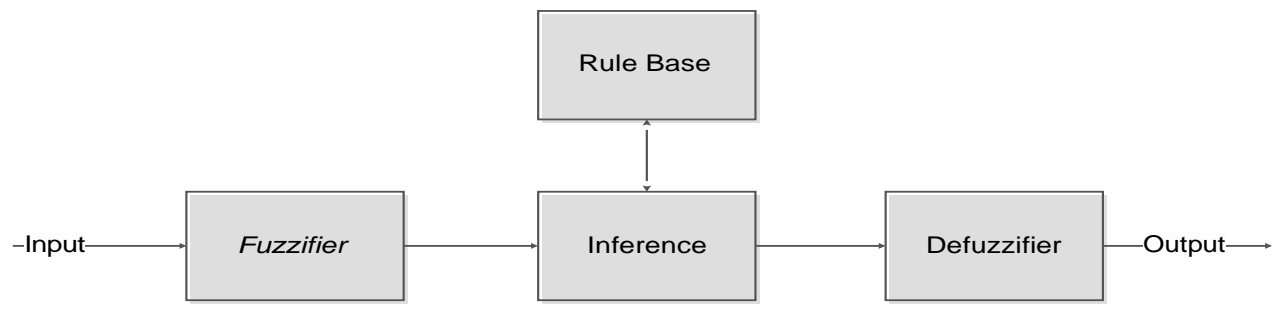

Gambar 3. Tahapan Fuzzy

\section{Fuzzifier}

Pada tahap ini, nilai keanggotaan himpunan permintaan dan persediaan saat ini dicari menggunakan fungsi keanggotaan himpunan fuzzy dengan memperhatikan nilai maksimum dan nilai minimum data dari tiap variabel. Variabel 1 periode terakhir antara lain: variabel nilai dan variabel angkatan.

\section{Rule Base}

Dalam tahap ke 2 (dua) yaitu penentuan Rule Base. Dengan mengkombinasikan himpunanhimpunan fuzzy tersebut, maka diperoleh 6 aturan fuzzy dengan cara matriks 3X2 lalu diusulkan terhadap narasumber.

\section{Inference}


Berikut ini tahap inferensi fuzzy yaitu langkah-langkah untuk mengkonversi empat aturan fuzzy tersebut sehingga diperolah nilai $\alpha$ dan $z$ dari setiap aturan.

\section{Defuzzifier}

Ketika nilai Z sudah ditemukan maka tahap terakhir yaitu Defuzzyfikasi Menggunakan metode rata-rata

\section{a. Hasil Perhitungan Metode}

Berikut merupakan hasil perhitungan metode Fuzzy dan K-Means pada aplikasi prediksi jumlah kelas

Hasil Perhitungan Metode Fuzzy

Perhitungan metode fuzzy digunakan untuk menentukan mahasiswa yang akan mengulang pada tahun ajaran selanjutnya. Berikut merupakan contoh perhitungan metode fuzzy [3] Kondisi $\quad$ : Jika mahasiswa nim 201531225 dan memiliki nilai C pada matakuliah Sistem Berkas pada semester 4

Pertanyaan : Mengulang atau tidak ?

b. Berdasarkan pembobotan normalisasi data, nilai $\mathrm{C}$ memiliki bobot 2 Fungsi keanggotaan.

1. Nilai

$$
\begin{aligned}
& \mu \text { Rendah [2] = } 0 \\
& \mu \text { Rendah [2] }=\frac{2,5-2}{2,5-1}=\frac{0,5}{1,5}=0,333 \\
& \mu \text { Sedang }[2]=\frac{2-1}{2,5-1}=\frac{1}{1,5}=0,667 \\
& \mu \text { Tinggi [2] = } 0 \\
& \mu \text { Akhir }[2014]=\frac{2017-2015}{2017-2013}=\frac{2}{4}=0,5 \\
& \mu \text { Awal [2014] }=\frac{2015-2013}{2017-2013}=\frac{2}{4}=0,5
\end{aligned}
$$

[R1] IF nilai TINGGI dan angkatan AWAL maka TIDAK mengulang

$\alpha$ - predikat $1=\mu$ Tinggi $\Pi \mu$ Awal

$$
=\min (0 ; 0,5)
$$

$$
=0
$$

Lihat himpunan hasil TIDAK mengulang

$$
Z_{1} \quad=1-(0) \times(1-0)
$$$$
=0
$$

[R2] IF nilai TINGGI dan angkatan AKHIR maka TIDAK mengulang

$\alpha-$ predikat $2=\mu$ Tinggi $\prod \mu$ Akhir

$$
=\min (0 ; 0,5)
$$

$$
=0
$$

Lihat himpunan hasil TIDAK mengulang

$\mathrm{Z}_{2} \quad=1-(0) \times(1-0)$

$$
=0
$$

[R3] IF nilai SEDANG dan angkatan AWAL maka MENGULANG 


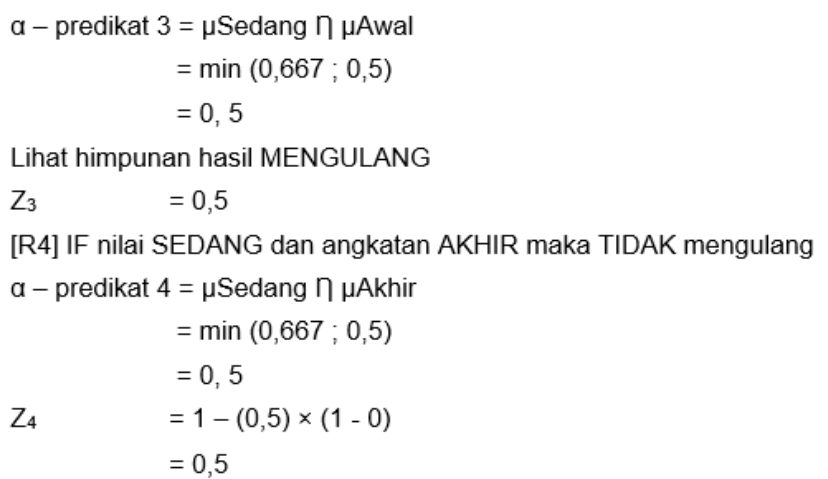

[R5] IF nilai RENDAH dan angkatan AWAL maka MENGULANG

$a-$ predikat $3=\mu$ Rendah $\eta \mu$ Awal

$=\min (0,333 ; 0,5)$

$=0,333$

Lihat himpunan hasil MENGULANG

$\mathrm{Z}_{5} \quad=0,333$

Hasil dari defuzzyfikasi yaitu 0,3418 maka hasilnya yaitu TIDAK MENGULANG karena kurang dari 0,5 termasuk ke daerah TIDAK MENGULANG

\section{c. Hasil Perhitungan Metode K-Means}

Pada penelitian ini penulis mencoba mengimplemntasikan metode K- Means untuk mengelompokkan matakuliah berdasarkan hasil prediksi mahasiswa yang akan mengulang menggunakan metode fuzzy tsukamoto.

Data hasil prediksi jumlah kelas semester ganjil tahun ajaran 2018/2019.

Data hasil prediksi jumlah kelas semester ganjil tahun ajaran 2018/2019:

\begin{tabular}{|c|c|c|c|c|c|}
\hline & \multicolumn{2}{|c|}{ SEKOLAH TINGGI TEKNIK - PLN } & & & \\
\hline & & FORM HAS & ;IL PRED & KSI & \\
\hline TAHUN & NAMA & JUMLAH YANG & JUMLAH & JUMLAH YANG & JUMLAH \\
\hline AKADEMIK & MATAKULIAH & SUDAH MENGAMBIL & MENGULANG & AKAN MENGAMBIL & KELAS \\
\hline 20181 & 1 PENDIDIKAN AGAMA & 211 & 24 & 148 & 5 \\
\hline 20181 & I PANCASILA & 258 & 20 & 188 & 6 \\
\hline 20181 & I BAHASA INGGRIS TEK & 210 & 7 & 275 & 8 \\
\hline 20181 & I ALGORITMA \& PEMRC & 109 & 27 & 144 & 5 \\
\hline 20181 & I TEKNOLOGI INFORM, & 183 & 11 & 101 & 3 \\
\hline 20181 & AUABAR LINIER & 238 & 4 & 138 & 4 \\
\hline 20181 & 1 LOGIKA MATEMATIKA & 159 & 7 & 256 & 7 \\
\hline 20181 & I FISIKA MEKANIKA & 241 & 6 & 237 & 7 \\
\hline 20181 & STRUKTUR DATA & 272 & 6 & 123 & 4 \\
\hline 20181 & I PEMROGRAMAN VISI & 224 & 24 & 142 & 5 \\
\hline 20181 & SISTEM OPERASI & 251 & 20 & 193 & 6 \\
\hline 20181 & KOMUNIKASI DATA & 134 & 23 & 231 & 7 \\
\hline 20181 & I PERANGKAT LUNAK J & 295 & 22 & 179 & 6 \\
\hline 20181 & I TEKNIK DIGITAL + PR/ & 238 & 29 & 271 & 8 \\
\hline 20181 & KALKULUS 2 & 229 & 25 & 235 & 7 \\
\hline
\end{tabular}

Gambar 4. Hasil Prediksi

Dari data diatas diketahui terdapat 6 kolom yang terdiri dari tahun akademik, nama matakuliah, jumlah yang sudah mengambil, jumlah mengulang dan jumlah. Metode KMeans adalah metode yang termasuk dalam algoritma clustering berbasis jarak yang membagi data ke dalam sejumlah cluster dan algoritma ini hanya bekerja pada atribut 
numerik maka setelah data dikelompokkan berdasarkan masing-masing kategori penilaiannya. Karena data yang ada berupa numerik maka tidak perlu dilakukan normalisasi atau pembobotan data. Atribut yang akan digunakan untuk perhitungan metode K- Means dalam mengelompokkan matakuliah yaitu jumlah yang sudah mengambil Langkah awal dari K-Means

- Menentukan jumlah kelompok yang ingin kita cari. Pada pengelompokkan matakuliah dibagi menjadi 2 kluster yaitu C1 DAN C2 denga nilai BANYAK, SEDIKIT.

- Penentuan Centroid awal berdasarkan nilai minimal data untuk C1(Sedikit) dan nilai maksimal data C2(Banyak) pada data matakuliah dan jumlah mengulang [6].

Berikut merupakan contoh perhitungan K-Means

Tabel 2. K-Means

\begin{tabular}{|c|c|c|}
\hline $\mathrm{C} 1$ & 2 & 118 \\
\hline $\mathrm{C} 2$ & 27 & 296 \\
\hline
\end{tabular}

Menghitung jarak objek pusat cluster dengan centroid dari data yang ada di masingmasing kelompok dengan rumus:

$$
\begin{aligned}
& \mathrm{d}(\mathrm{x}, \mathrm{y})=|x-y|=\sqrt{\sum_{i=1}^{n}\left(x_{i}-y_{i}\right)^{2}} \\
& \text { Iterasi } 1 \\
& \text { DC1 } \\
& \text { Pendidikan Agama } \quad=\underline{\underline{\sqrt{ }}}(4-2)^{2}+(296-118)^{2} \\
& =178,011 \\
& \text { Pancasila } \quad=\underline{\underline{\sqrt{ }}(2-2)^{2}+(161-118)^{2}} \\
& =43 \\
& \text { Bahasa Inggris Teknik }=\underline{\underline{\sqrt{ }}(18-2)^{2}+(294-118)^{2}} \\
& =176,726 \\
& \text { Algoritma } \quad=\underline{\underline{\sqrt{ }}(6-2)^{2}}+(168-118)^{2} \\
& \text { Pemrograman } 1 \quad=50,1597 \\
& \text { Teknologi Informasi } \quad=\underline{\underline{\sqrt{ }}(15-2)^{2}+(118-296)^{2}} \\
& =13 \\
& \text { DC2 } \\
& \text { Pendidikan Agama } \quad=\underline{\underline{\sqrt{ }}}(4-16)^{2}+(296-296)^{2}
\end{aligned}
$$


PETIR: Jurnal Pengkajian dan Penerapan Teknik Informatika

Vol. 12, No. 2, September 2019, P-ISSN 1978-9262, E-ISSN 2655-5018

$\begin{array}{ll} & =23 \\ \text { Pancasila } & =\underline{\underline{\sqrt{ }}(2-16)^{2}+(161-296)^{2}} \\ & =137,295 \\ \text { Bahasa Inggris Teknik } & =\underline{\underline{\sqrt{ }}(18-16)^{2}+(294-296)^{2}} \\ & =9,219 \\ \text { Algoritma } & =\underline{\underline{\sqrt{ }}} 6-16)^{2}+(168-296)^{2} \\ \text { Pemrograman } 1 & =129,711 \\ \text { Teknologi Informasi } & =\underline{\underline{\sqrt{ }}} 15-16)^{2}+(118-245)^{2} \\ & =178,404\end{array}$

Kelompokkan data hasil kuster berdasarkan jarak terdekat antara data dengan pusat cluster.

Tabel 3. Hasil kluster 1 berdasarkan jarak terdekat

\begin{tabular}{|c|c|c|c|}
\hline Matakuliah & \begin{tabular}{|l|} 
prediksi jumlah \\
mengulang
\end{tabular} & $\begin{array}{lr}\text { jumlah yang } \\
\text { sudah mengambil }\end{array}$ & $\begin{array}{l}\text { ITER } \\
\text { ASI } 1\end{array}$ \\
\hline PENDIDIKAN AGAMA & 4 & 296 & $\mathrm{C} 2$ \\
\hline PANCASILA & 2 & 161 & C1 \\
\hline BAHASA INGGRIS TEKNIK & 18 & 294 & $\mathrm{C} 2$ \\
\hline $\begin{array}{lll}\text { ALGORITMA } & & \text { \& } \\
\text { PEMROGRAMAN } & 1 & + \\
\text { PRAKTEK } & & \end{array}$ & 6 & 168 & C1 \\
\hline TEKNOLOGI INFORMASI & 15 & 118 & C1 \\
\hline ALJABAR LINIER & 4 & 277 & $\mathrm{C} 2$ \\
\hline LOGIKA MATEMATIKA & 16 & 245 & $\mathrm{C} 2$ \\
\hline FISIKA MEKANIKA & 12 & 255 & $\mathrm{C} 2$ \\
\hline STRUKTUR DATA & 13 & 210 & $\mathrm{C} 2$ \\
\hline PEMROGRAMAN VISUAL & 17 & 118 & C1 \\
\hline
\end{tabular}

Tabel 4. Hasil kluster 2 berdasarkan jarak terdekat

\begin{tabular}{|l|l|l|l|}
\hline Matakuliah & $\begin{array}{l}\text { prediksi jumlah } \\
\text { mengulang }\end{array}$ & $\begin{array}{l}\text { jumlah yang } \\
\text { sudah mengambil }\end{array}$ & $\begin{array}{l}\text { ITER } \\
\text { ASI } 1\end{array}$ \\
\hline SISTEM OPERASI & 13 & 196 & C1 \\
\hline KOMUNIKASI DATA & 15 & 282 & C2 \\
\hline $\begin{array}{l}\text { PERANGKAT LUNAK } \\
\text { JARINGAN 1 }\end{array}$ & 27 & 208 & C2 \\
\hline $\begin{array}{l}\text { TEKNIK DIGITAL } \\
\text { PRAKTEK }\end{array}$ & 9 & 283 & C2 \\
\hline KALKULUS 2 & 13 & 281 & $\mathrm{C} 2$ \\
\hline FISIKA LISTRIK \& MAGNET & 8 & 253 & $\mathrm{C} 2$ \\
\hline SUMBER DAYA ENERGI & 3 & 276 & $\mathrm{C} 2$ \\
\hline SISTEM INFORMASI & 5 & 276 & $\mathrm{C} 2$ \\
\hline PEMROGRAMAN SQL & 2 & 118 & $\mathrm{C} 1$ \\
\hline TEKNIK KOMPILASI & 27 & 296 & $\mathrm{C} 2$ \\
\hline
\end{tabular}

Mencari nilai centroid baru untuk masing-masing nilai C1 dan C2 Nilai centroid untuk $\mathrm{C} 1$ 
Tabel 5. Mencari nilai centroid baru 1

\begin{tabular}{|l|l|l|l|}
\hline Matakuliah & $\begin{array}{l}\text { Prediksi } \\
\text { Mahasiswa } \\
\text { Mengulang }\end{array}$ & $\begin{array}{l}\text { Mahasiswa } \\
\text { yang sudah } \\
\text { mengambil }\end{array}$ & $\begin{array}{l}\text { Kelompok } \\
\text { C1 }\end{array}$ \\
\hline PANCASILA & 2 & 161 & $\mathrm{C} 1$ \\
\hline $\begin{array}{l}\text { ALGORITMA \& PEMROGRAMAN } \\
1+\text { PRAKTEK }\end{array}$ & 6 & 168 & $\mathrm{C} 1$ \\
\hline TEKNOLOGI INFORMASI & 15 & 118 & $\mathrm{C} 1$ \\
\hline PEMROGRAMAN VISUAL & 17 & 118 & $\mathrm{C} 1$ \\
\hline SISTEM OPERASI & 13 & 196 & $\mathrm{C} 1$ \\
\hline PEMROGRAMAN SQL & 2 & 118 & $\mathrm{C} 1$ \\
\hline
\end{tabular}

Nilai centroid baru masing-masing $\mathrm{k}$ di peroleh dari nilai rata-rata tiap kolom.

$=\frac{\text { Data }}{\text { Iumian Vata }}$

$=9,16667=146,5$

Tabel 6. Mencari nilai centroid baru 2

\begin{tabular}{|c|c|c|c|}
\hline Matakuliah & $\begin{array}{l}\text { Prediksi } \\
\text { Mahasiswa } \\
\text { Mengulang }\end{array}$ & $\begin{array}{l}\text { Mahasiswa yang } \\
\text { sudah mengambil }\end{array}$ & $\begin{array}{l}\text { Kelomp } \\
\text { ok C2 }\end{array}$ \\
\hline $\begin{array}{l}\text { PENDIDIKAN } \\
\text { AGAMA }\end{array}$ & 4 & 296 & $\mathrm{C} 2$ \\
\hline $\begin{array}{l}\text { BAHASA INGGRIS } \\
\text { TEKNIK }\end{array}$ & 18 & 294 & $\mathrm{C} 2$ \\
\hline ALJABAR LINIER & 4 & 277 & $\mathrm{C} 2$ \\
\hline $\begin{array}{l}\text { LOGIKA } \\
\text { MATEMATIKA }\end{array}$ & 16 & 245 & $\mathrm{C} 2$ \\
\hline FISIKA MEKANIKA & 12 & 255 & $\mathrm{C} 2$ \\
\hline STRUKTUR DATA & 13 & 210 & $\mathrm{C} 2$ \\
\hline KOMUNIKASI DATA & 15 & 282 & $\mathrm{C} 2$ \\
\hline $\begin{array}{l}\text { PERANGKAT } \\
\text { LUNAK JARINGAN } 1\end{array}$ & 27 & 208 & $\mathrm{C} 2$ \\
\hline $\begin{array}{l}\text { TEKNIK DIGITAL + } \\
\text { PRAKTEK }\end{array}$ & 9 & 283 & $\mathrm{C} 2$ \\
\hline KALKULUS 2 & 13 & 281 & $\mathrm{C} 2$ \\
\hline $\begin{array}{l}\text { FISIKA LISTRIK \& } \\
\text { MAGNET }\end{array}$ & 8 & 253 & $\mathrm{C} 2$ \\
\hline $\begin{array}{l}\text { SUMBER } \\
\text { ENERGI }\end{array}$ & 3 & 276 & $\mathrm{C} 2$ \\
\hline $\begin{array}{l}\text { SISTEM } \\
\text { INFORMASI }\end{array}$ & 5 & 276 & $\mathrm{C} 2$ \\
\hline TEKNIK KOMPILASI & $27 \mid$ & 296 & $\mathrm{C} 2$ \\
\hline
\end{tabular}

Nilai centroid baru masing-masing $\mathrm{k}$ di peroleh dari nilai rata-rata tiap kolom

$$
\begin{aligned}
& =\frac{\text { Data }}{\text { Jumian Vata }} \\
& =12,4286 \\
& =266,571
\end{aligned}
$$

Iterasi 2

Tabel 7. Hasil nilai centroid baru

\begin{tabular}{|l|l|l|}
\hline C1 & 9,166667 & 146,5 \\
\hline C2 & 12,42857 & 266,5714 \\
\hline
\end{tabular}


PETIR: Jurnal Pengkajian dan Penerapan Teknik Informatika

Vol. 12, No. 2, September 2019, P-ISSN 1978-9262, E-ISSN 2655-5018

$$
\begin{aligned}
& \text { DC1 } \\
& \text { Pendidikan Agama } \quad=\underline{\underline{ }}(4-9,1667)^{2}+(296-146,5)^{2} \\
& =149,589 \\
& \text { Pancasila } \quad=\underline{\underline{\sqrt{ }}(2-9,1667)^{2}+(161-146,5)^{2}} \\
& =16,1744 \\
& \text { Bahasa Inggris Teknik }=\underline{\underline{J}}(18-9,1667)^{2}+(294-146,5)^{2} \\
& =147,764 \\
& \text { Algoritma } \\
& \text { Pemrograman } 1 \\
& =\underline{\underline{\sqrt{ }}}(6-9,1667)^{2}+(168-146,5)^{2} \\
& =21,732 \\
& \text { Teknologi Informasi } \quad=\underline{\underline{J}}(15-9,1667)^{2}+(118-146,5)^{2} \\
& =29,0909 \\
& \text { Pendidikan Agama } \quad=\underline{\underline{J}}(4-13,5)^{2}+(296-179,2)^{2} \\
& =30,6118 \\
& \text { Pancasila } \quad=\underline{\underline{\sqrt{ }}(2-13,5)^{2}+(161-179,2)^{2}} \\
& =106,085 \\
& \text { Bahasa Inggris Teknik } \quad=\underline{\underline{\sqrt{ }}}(18-13,5)^{2}+(294-179,2)^{2} \\
& =27,9887 \\
& \text { Algoritma } \quad=\underline{\underline{ }}(6-13,5)^{2}+(168-179,2)^{2} \\
& \text { Pemrograman } 1 \quad=98,7808 \\
& \text { Teknologi Informasi } \quad=\underline{\underline{\sqrt{ }}}(15-13,5)^{2}+(118-179,2)^{2} \\
& =148,594
\end{aligned}
$$

Kelompokkan data hasil kluster berdasarkan jarak terdekat antara data dengan pusat cluster.

Tabel 8. Penentuan Kluster Iterasi 1

\begin{tabular}{|l|l|l|l|}
\hline Matakuliah & $\begin{array}{l}\text { prediksi iumlah } \\
\text { mengulang }\end{array}$ & $\begin{array}{l}\text { iumlah yang } \\
\text { sudah mengambil }\end{array}$ & $\begin{array}{l}\text { TTER } \\
\text { ASI 2 }\end{array}$ \\
\hline PENDIDIKAN AGAMA & 4 & 296 & C2 \\
\hline PANCASILA & 2 & 161 & C1 \\
\hline BAHASA INGGRIS TEKNIK & 18 & 294 & C2 \\
\hline $\begin{array}{l}\text { ALGORITMA \& } \\
\text { PEMROGRAMAN 1 + } \\
\text { PRAKTEK }\end{array}$ & 6 & 168 & C1 \\
\hline TEKNOLOGI INFORMASI & 15 & 118 & C1 \\
\hline ALJABAR LINIER & 4 & 277 & C2 \\
\hline LOGIKA MATEMATIKA & 16 & 245 & C2 \\
\hline
\end{tabular}


Tabel 9. Penentuan Kluster Iterasi 1

\begin{tabular}{|l|l|l|l|}
\hline Matakuliah & $\begin{array}{l}\text { prediksi iumlah } \\
\text { mengulang }\end{array}$ & $\begin{array}{l}\text { iumlah yang } \\
\text { sudah mengambil }\end{array}$ & $\begin{array}{l}\text { ITER } \\
\text { ASI 2 }\end{array}$ \\
\hline FISIKA MEKANIKA & 12 & 255 & C2 \\
\hline STRUKTUR DATA & 13 & 210 & C2 \\
\hline PEMROGRAMAN VISUAL & 17 & 118 & C1 \\
\hline SISTEM OPERASI & 13 & 196 & C1 \\
\hline KOMUNIKASI DATA & 15 & 282 & C2 \\
\hline $\begin{array}{l}\text { PERANGKAT LUNAK } \\
\text { JARINGAN 1 }\end{array}$ & 27 & 208 & C2 \\
\hline $\begin{array}{l}\text { TEKNIK DIGITAL } \\
\text { PRAKTEK }\end{array}$ & 9 & 283 & C2 \\
\hline KALKULUS 2 & 13 & 281 & C2 \\
\hline FISIKA LISTRIK \& MAGNET & 8 & 253 & C2 \\
\hline SUMBER DAYA ENERGI & 3 & 276 & C2 \\
\hline SISTEM INFORMASI & 5 & 276 & C2 \\
\hline PEMROGRAMAN SQL & 19 & 233 & C2 \\
\hline TEKNIK KOMPILASI & 7 & 135 & \\
\hline
\end{tabular}

Membandingkan hasil iterasi-1 dan iterasi-2, jika masih ada data hasil cluster yang belum sesuai makan iterasi dilanjutkan sampai hasil kluster nilai $\mathrm{C} 1$ dan $\mathrm{C} 2$ sesuai semua.

Perbandingan Iterasi 1 dan Iterasi 2

Tabel 10. Perbandingan Iterasi 1

\begin{tabular}{|l|l|l|}
\hline ITERASI 2 & ITERASI 1 & Hasil \\
\hline C2 & C2 & SESUAI \\
\hline C1 & C1 & SESUAI \\
\hline C2 & C2 & SESUAI \\
\hline C1 & C1 & SESUAI \\
\hline C1 & C1 & SESUAI \\
\hline C2 & C2 & SESUAI \\
\hline C2 & C2 & SESUAI \\
\hline C2 & C2 & SESUAI \\
\hline C2 & C2 & SESUAI \\
\hline
\end{tabular}

Tabel 11. Perbandingan Iterasi 2

\begin{tabular}{|l|l|l|}
\hline ITERASI 2 & ITERASI 1 & Hasil \\
\hline C1 & C1 & SESUAI \\
\hline C1 & C1 & SESUAI \\
\hline C2 & C2 & SESUAI \\
\hline C2 & C2 & SESUAI \\
\hline C2 & C2 & SESUAI \\
\hline C2 & C2 & SESUAI \\
\hline C2 & C2 & SESUAI \\
\hline C2 & C2 & SESUAI \\
\hline C2 & C2 & SESUAI \\
\hline C1 & C1 & SESUAl \\
\hline C2 & C2 & SESUAI \\
\hline
\end{tabular}

Membandingkan hasil iterasi-2 dan iterasi-1, karena sudah tidak data yang berpindah centroid maka iterasi sudah selesai. Berikut hasil pengelompokkan matakuliah menggunakan metode K-Means. 
Hasil Pengelompokkan Matakuliah C1

Tabel 12. Hasil Pengelompokkan Matakuliah C1

\begin{tabular}{|c|c|c|c|}
\hline Matakuliah & $\begin{array}{l}\text { Riediksi } \\
\text { Mahassiswa } \\
\text { Mengullana }\end{array}$ & $\begin{array}{l}\text { Mahassiswar yang } \\
\text { sudah menoambil }\end{array}$ & $\begin{array}{l}\text { ITER } \\
\text { ASI } 2\end{array}$ \\
\hline PANCASILA & 2 & 161 & C1 \\
\hline $\begin{array}{ll}\text { ALGORITMA } & \& \\
\text { PEMROGRAMAN } & 1+ \\
\text { PRAKTEK } & \end{array}$ & 6 & 168 & C1 \\
\hline TEKNOLOGI INFORMASI & 15 & 118 & C1 \\
\hline PEMROGRAMAN VISUAL & 17 & 118 & C1 \\
\hline SISTEM OPERASI & 13 & 196 & C1 \\
\hline PEMROGRAMAN SQL & 2 & 118 & $\mathrm{C1}$ \\
\hline
\end{tabular}

Tabel diatas merupakan hasil pengelompokkan matakuliah dengan predikat banyak berdasarkan jumlah mahasiswa yang sudah mengambil dan jumlah mahasiswa yang mengulang menggunakan metode K-Means.

Tabel 13. Hasil Pengelompokkan Matakuliah C2

\begin{tabular}{|c|c|c|c|}
\hline Matakuliah & $\begin{array}{l}\text { Rrediksi Mabasiswa } \\
\text { Mengulang }\end{array}$ & $\begin{array}{l}\text { Mabasiswa yang } \\
\text { sudah mengambil }\end{array}$ & $\begin{array}{l}\text { Itera } \\
\text { si } 2\end{array}$ \\
\hline PENDIDIKAN AGAMA & 4 & 296 & $\mathrm{C} 2$ \\
\hline $\begin{array}{l}\text { BAHASA INGGRIS } \\
\text { TEKNIK }\end{array}$ & 18 & 294 & $\mathrm{C} 2$ \\
\hline ALJABAR LINIER & 4 & 277 & $\mathrm{C} 2$ \\
\hline $\begin{array}{l}\text { LOGIKA } \\
\text { MATEMATIKA }\end{array}$ & 16 & 245 & $\mathrm{C} 2$ \\
\hline FISIKA MEKANIKA & 12 & 255 & $\mathrm{C} 2$ \\
\hline STRUKTUR DATA & 13 & 210 & $\mathrm{C} 2$ \\
\hline KOMUNIKASI DATA & 15 & 282 & $\mathrm{C} 2$ \\
\hline $\begin{array}{l}\text { PERANGKAT LUNAK } \\
\text { JARINGAN } 1\end{array}$ & 27 & 208 & $\mathrm{C} 2$ \\
\hline $\begin{array}{l}\text { TEKNIK DIGITAL + } \\
\text { PRAKTEK }\end{array}$ & 9 & 283 & $\mathrm{C} 2$ \\
\hline KALKULUS 2 & 13 & 281 & $\mathrm{C} 2$ \\
\hline $\begin{array}{l}\text { FISIKA LISTRIK \& } \\
\text { MAGNET }\end{array}$ & 8 & 253 & $\mathrm{C} 2$ \\
\hline $\begin{array}{ll}\text { SUMBER } & \text { DAYA } \\
\text { ENERGI } & \end{array}$ & 3 & 276 & $\mathrm{C} 2$ \\
\hline SISTEM INFORMASI & 5 & 276 & $\mathrm{C} 2$ \\
\hline TEKNIK KOMPILASI & 27 & 296 & $\mathrm{C} 2$ \\
\hline
\end{tabular}

\section{d. Validasi Penerapan Metode}

Pengujian akurasi sistem aplikasi menggunakan perbandingan antara jumlah kelas yang ada pada blanko RPM dengan hasil dari aplikasi prediksi jumlah kelas. Pengujian ini dinilai berdasarkan kesesuaian setiap data yang digunakan antara hasil yang ada dengan hasil prediksi. Dengan perumusan sebagai berikut:

Data pembelajaran dan testing adalah data jumlah kelas untuk setiap matakuliah. Matakuliah yang akan diuji coba adalah Pendidikan Agama, Pancasila, Bahasa Inggris Teknik, Algoritma dan Pemorgrama 1 + praktek, Teknologi Informasi, Aljabar Linier, 
Logika Matematika, Fisika Mekanika, Struktur Data, Pemrograman Visual, Sistem Operasi, Komunikasi Data, Perangkat Lunak Jaringan 1, Teknik Digital + Praktek, dan Kalkulus 2

Tabel 14. Tabel Pengujian Akurasi

\begin{tabular}{|c|c|c|c|}
\hline Nilai & \multicolumn{3}{|c|}{ Nilai Sebenarnya } \\
\hline \multirow{3}{*}{ Nilai Rcediksi } & T/F & TRUE & FALSE \\
\cline { 2 - 4 } & TRUE & $\underline{\underline{\text { IP(True Positive) }}}$ & EP(False Positive) \\
\cline { 2 - 4 } & FALSE & $\underline{\text { FN(False Negative) }}$ & $\underline{\underline{\text { IN(True Negative) }}}$ \\
\hline
\end{tabular}

Berikut merupakan rumus untuk menghitung akurasi antara nilai sebenarnya dengan nilai prediksi :

$$
\text { Accuracy }=\frac{T P+T N}{T P+T N+F P+F N}
$$

Tabel 15. Matakuliah Yang Akan di Ujicoba

\begin{tabular}{|l|r|r|}
\hline \multirow{2}{*}{ Matakuliah } & \multicolumn{2}{c|}{ iumlah kelas } \\
\cline { 2 - 3 } & $\begin{array}{l}\text { iumlah } \\
\text { sebenarnya }\end{array}$ & prediksi \\
\hline PENDIDIKAN AGAMA & 4 & 4 \\
\hline PANCASILA & 5 & 5 \\
\hline BAHASA INGGRIS TEKNIK & 7 & 7 \\
\hline ALGORITMA \& PEMROGRAMAN 1 + & 4 & 4 \\
PRAKTEK & & 3 \\
\hline TEKNOLOGI INFORMASI & 3 & 3 \\
\hline ALJABAR LINIER & 4 & 4 \\
\hline LOGIKA MATEMATIKA & 7 & 7 \\
\hline FISIKA MEKANIKA & 6 & 6 \\
\hline STRUKTUR DATA & 3 & 4 \\
\hline PEMROGRAMAN VISUAL & 4 & 4 \\
\hline SISTEM OPERASI & 6 & 6 \\
\hline KOMUNIKASI DATA & 6 & 6 \\
\hline
\end{tabular}

\begin{tabular}{|l|r|r|}
\hline \multirow{2}{*}{ Matakuliah } & \multicolumn{2}{|c|}{ iumlah kelas } \\
\cline { 2 - 4 } & $\begin{array}{l}\text { iumlah } \\
\text { sebenarnya }\end{array}$ & prediksi \\
\hline PERANGKAT LUNAK JARINGAN 1 & 5 & 5 \\
\hline TEKNIK DIGITAL + PRAKTEK & 7 & 8 \\
\hline KALKULUS 2 & 6 & 7 \\
\hline
\end{tabular}

Akurasi Hasil jumlah kelas

Tabel 16. Akurasi Hasil Jumlah Kelas

\begin{tabular}{c|c|c|c|}
\hline Nilai & \multicolumn{3}{|c|}{ Nilai Sebenarnya } \\
\hline Nilai Rcediksi & T/F & TRUE & FALSE \\
\cline { 2 - 4 } & TRUE & 12 & 0 \\
\cline { 2 - 4 } & FALSE & 3 & 0 \\
Accuracy $=\frac{12+0}{12+3+0+0}=0,8 \times 100 \%=80$
\end{tabular}

Berdasarkan hasil pada table akurasi eeror diatas tingkat keberhasilan metode Fuzzy yaitu $80 \%$

\section{Hasil}

Aplikasi prediksi kelas suatu matakuliah ini dibuat dengan menggunakan metode Fuzzy Tsukamoto dan metode klustering K-Means. Pengumpulan data dilakukan dengan cara studi pustaka untuk beberpa jurnal dan buku terkait masalah prediksi menggunakan metode Fuzzy dan metode KMeans, wawancara untuk mendapatkan informasi dengan mengadakan dialog langsung dengan 
narasumber terkait yaitu sekretaris Jurusan Teknik Informatika untuk mendapatkan infromasi secara detail mengenai permasalahan dalam penulisan ini, serta melakukan observasi dan quesioner untuk memperkuat masalah. Sistem aplikasi yang dikembangkan untuk memudahkan pihak jurusan untuk memprediksi jumlah kelas setiap matakuliah.

Pada aplikasi ini metode fuzzy digunakan untuk memprediksi mahasiswa yang memiliki kemungkinan mengulang pada suatu matakuliah dengan menggunakan variabel angkatan dan nilai mahasiswa. Masing-masing variabel ditentukan himpunan keanggotaan dan fungsi keanggotaan untuk dimasukkan ke dalam sebuah kondisi(rules), kemudian hasil dari setiap rules dihitung menggunakan rumus defuzzyfikasi. Nilai yang dihasilkan pada tahap defuzzyfikasi dikelompokkan jika nilai kurang dari 0,5 hasilnya tidak menulang, dan jika hasilnya lebih dari sama dengan 0,5 maka hasilnya mengulang. Hasil predksi jumlah mrengulang diakumulasikan dengan jumlah mahasiswa yang seharusnya akan mengambil kemudian dibagi 40 untuk mendapatkan prediksi jumlah kelas. Setelah mendapatkan hasil, setiap matakuliah dikelompokkan menjadi 3 kluster dengan menggunakan metode K-Means

\section{KESIMPULAN DAN SARAN}

a. Kesimpulan

Berdasarkan hasil penelitian dan pembahasan yang telah dilakukan dapat diambil beberapa kesimpulan, antara lain:

1. Proses penentuan jumlah kelas setiap matakuliah pada sistem berjalan berdasarkan jumlah kelas setiap matakulliah semester sebelumnya dan persentase nilai mahasiswa yang tidak lulus suatu matakuliah.

2. Metode Fuzzy dapat memprediksi mahasiswa yang akan mengulang atau tidak berdasarkan nilai dan angkatan mahasiswa tersebut dengan menentukan himpunan keanggotaan dan fungsi keanggotaan kemudian diimpikasikan ke dalam rules yang telah ditentukan. Dari hasil metode k- means dapat digunakan untuk mengelompokkan matakuliah yang terdapat kemungkinan mahasiswa mengulang menjadi 2 kluster yaitu banyak dan sedikit menggunakan metode klustering K-Means. Hasil dari prediksi jumlah kelas menghasilkan tingkat keakurasian sebesar $80 \%$ dengan menggunakan metode keakurasian Confusion Matrix Accuracy.

\section{b. Saran}

Dari hasil penelitian yang telah dilaksanakan, terdapat beberapa hal

1. Jika dilakukan pengembangan terhadap penelitian ini dapat menambahkan variabel yang digunakan untuk memprediksi mahasiwa yang akan mengulang suatu matakuliah.

2. Bagi peneliti lain yg ingin melakuklan penenlitian untuk memprediksi jumlah kelas dapat menggunakan metode lain.

\section{UCAPAN TERIMA KASIH}

Penulis mengucapkan terima kasih kepada Tim PDSI STT-PLN yang telah memberi dukungan yang membantu pelaksanaan penelitian dan atau penulisan artikel.

\section{DAFTAR PUSTAKA}

[1] Maulidinnawati, A., Parewe, A. K., \& Firdaus Mahmudy, W. (2016). Seleksi Calon Karyawan Menggunakan Metode Fuzzy Tsukamoto. Seminar Nasional Teknologi Informasi Dan Komunikasi, 2089-9815. Retrieved from https://fti.uajy.ac.id/sentika/publikasi/makalah/2016/71.pdf

[2] Dili Giyanti, E. (2017). Penerapan Logika Fuzzy Untuk Menentukan Mahasiswa Berprestasi di STMIK Cikarang MEnggunakan Java Netbeans dan MYSQL. Jurnal Informatika 
SIMANTIK, 2(September), 77-84. https://doi.org/10.24961/j.tek.ind.pert.2017.27.2.141

[3] Kusumadewi, S., \& Purnomo, H. (2013). Aplikasi Logika Fuzzy untuk Pendukung Keputusan (2nd ed.). Graha Ilmu.

[4] Tsukamoto for Decision Making in Crude Palm Oil Production Planning. 2016 International Conference on Industrial Engineering and Operations Management, 2206-2210

[5] Bon, A. T., \& Utami, S. F. (2016). Applying Fuzzy Inference System.

[6] Chaudhari, S., \& Patil, M. (2014). Study and Review of Fuzzy Inference Systems for Decision Making and Control. American International Journal of Research in Science, 14-147. Retrieved from http://www.iasir.net.

[7] Mardani, A., Jusoh, A., \& Zavadskas, E. K. (2015). Fuzzy multiple criteria decision-making techniques and applications â $€$ " Two decades review from 1994 to 2014. Expert Systems With Applications, 42, 4126-4148. https://doi.org/10.1016/j.eswa.2015.01.003

[8] Sangadji, I., \& Arvio, Y. (2018, March). Dynamic Segmentation Of Behavior Patterns Based On Quantity Value Movement Using Fuzzy Subtractive Clustering Method. In Journal of Physics: Conference Series (Vol. 974, No. 1, p. 012009). IOP Publishing.

[9] Siregar, R., Siregar, Z., \& Arianto, R. (2019). Klasifikasi Sentiment Analysis Pada Komentar Peserta Diklat Menggunakan Metode K-Nearest Neighbor. KILAT, 8(1). https://doi.org/10.33322/kilat.v8i1.421

[10] A., Arianto, R., Indrianto, I., \& Nugroho, B. (2018). The Obstacles Detector with Tahani Fuzzy Logic as The Tool for Blind People. Lontar Komputer: Jurnal Ilmiah Teknologi Informasi, 72-80. doi:10.24843/LKJITI.2018.v09.i02.p02 